\title{
Pathology and treatments of obesity
}

Da-Yong Lu ${ }^{1 *}$, Jin-Yu Che ${ }^{1}$, Ting-Ren Lu' ${ }^{1}$, Yi Lu ${ }^{2}$, Yong-Kang Huang ${ }^{3}$, Ting-Lan Lu ${ }^{3}$, Yu-Zhen Chen ${ }^{3}$, Hong-Ying Wu ${ }^{1}$ and Da-Feng Lu ${ }^{3}$

${ }^{1}$ Shanghai University, Shanghai, PR China

${ }^{2}$ Shanghai Ocean University, Shanghai, PR China

${ }^{3}$ The Second Hospital of Neijiang District, Sichuan Province, PR China

\begin{abstract} treatment study.

\section{Background}

Obesity is an undesired phenotype/symptom that causes a lot of troubles obese people [1-3]. However, it is difficult to be remedied by existing management measures and resources via shortage of pathological and therapeutic knowledge globally. Many types of therapeutic/management measures have been developed for this symptom-some of these measures are even very expensive (surgery) or harmful for the sufferers (dietary control or increase of nutrition excretion) [1-3]. Usually, body-weight loss effort fails after discontinuation of therapies.
\end{abstract}

Obesity is prevalence globally. About 35-36\% adults in the US are suffered with obesity. Many types of therapeutic/management measures have been developed for this symptom. Body-weight loss often fails after discontinuation of life-style and therapeutic efforts. This article tries to shed new light on obese pathology and

\section{Global situation}

Approximately $1 / 4$ to $1 / 3$ of global adult population is obesity (body mass index > 30) [4]. The co-morbidity of obese persons with many other diseases, such as depression, diabetes, cardiovascular risks and so on is very troublesome in the clinic [2-12]. In addition, obese youngsters often meet with some kinds of other embarrassment such as episode of romance failures in blind-date, difficult to find decent jobs and lower possibility of position promotion [2-4]. From these obese sufferers, losing weight is their first choice and addictive with. This editorial will outline pathological and therapeutic information we know about.

Generally speaking, purposed weight loss is a great pain and agonizing. Only small proportion of obese people can success in the clinic. Many people, especially personal practice regain their weight after therapeutic discontinuation. As a result, most obese people struggle with this problem in a long-term. To solve with this therapeutic weak point, pathological or therapeutic study and knowledge accumulation is the key.

\section{Etio-pathologic knowledge}

Human obesity is caused by a lot of different environmental or morbidity factors-including [2-3];

Overfeed

Energy disturbance
Pathologic factorials

Sedentary (less physical exercises)

Gastro-intestinal abnormal

Psychiatric burden

Behavior (alcoholic and laziness)

Chemical or drug-induced

Tumor-induced

Physiological change (neural-appetite axis)

Inheritance (genetic/epigenetic)

Hormonal or blood glucose level escalations

\section{Major counteractive measures [13-17]}

Diet-control

Consumption of more fresh fruits, vegetable and seafood

Life-style adjustments (exercises, Yoga, athletics, ball-games and meditation)
Surgery (gastric bariatric surgery)
Chemical drugs
Biotherapy
Psychiatric intervention
Therapeutic combinations

${ }^{*}$ Correspondence to: Da-Yong Lu, Shanghai University, Shanghai, PR China, E-mail: ludayong@shu.edu.cn

Key words: obesity, diabetes, endocrinology

Received: August 27, 2018; Accepted: September 10, 2018; Published: September 12, 2018 


\section{Future directions}

Obese therapeutics and managements should target on human inflammatory homeostasis, etio-pathological pathways and energy disturbance/imbalance-including life-style adjustments, energy homeostasis and lipo-dystrophy. Without these targeted therapeutics, clinical obese therapy will not be able to completely reliance, cheap and less toxicity to diseased people. This is the ultimate goal of pharmaceutical company and clinical doctors.

Genomic study of obesity might bring us many new insights into this chronic phenotype/symptom [1-3,18-20]. Along with the advance of other diseases, the patho-therapeutic knowledge of obesity might be improved by this genomic approach in the future.

Therapeutic combinations are also very useful for obese patients. These kinds of therapeutic paradigms are very useful for many other diseases [21-24]. Similar work in this regard (large-scale in vitro and in vivo experimental study) is inevitable in the future.

Natural chemotherapeutic agents or drugs might be more effective against obese onset, metabolic syndrome and progresses [25-27]. Today, many chemical or herbal drugs are the main sources of obese control and treatments. Certainly, life-style adjustments are well assistance to these natural drugs and many other therapeutic targets, such as leptin, insulin and many others.

\section{Conclusion}

Many therapeutics can help us to manage overweight and even obesity in the clinic. However, there is a long way to go for completely managing all obese people. We need to promote these researches in the near future. Look forward to new generation of medical breakthroughs for obese control and managements.

\section{Acknowledgment}

This work was funded by Shanghai Science and Technology Foundation of High Education 97A49.

\section{Conflict of interests}

None.

\section{References}

1. World Health Organization. WHO (2018) Obesity and overweight. Access February 18, 2018. http//www.who.int/topics/obesity/en/

2. Lu DY, Che JY, Wu HY, Yarla NS, Xu B, et al. (2018) Obesity, risks and managements. Metabolomics 8: e156.

3. Lu DY, Che JY, Lu Y, Wu HY, Yarla NS, et al. (2018) An overview of obesity. Metabolomics 8: 200.

4. Brestoff JR, Artis D (2015) Immune regulation of metabolic homeostasis in health and disease. Cell 161: 146-160. [Crossref]

5. Lu DY, Che JY, Yarla NS, Zhu H, Lu TR, et al. (2018) Type 2 diabetes study, introduction and perspective. The Open Diabetes Journal 8: 13-21.
6. Lu DY, Che JY, Yarla NS, Wu HY, Lisa D, et al. (2017) Diabetes prevention and treatments, a specific topic for modern medicines. J Metabolic Syndrome 8: 231

7. Lu DY, Che JY, Yarla NS, Wu HY, Xu B, et al. (2017) Type 2 diabetes, medical knowledge and pharmaceutical innovations. J Diabetology 1: 1-3.

8. Ahmad, Shamim (Ed.) (2013) Diabetes - An Old Disease, A New Insights. Springer Science, US, ISBN 978-1-4614-5440-3.

9. Zimmet PZ, Magliano DJ, Herman WH, Shaw JE (2014) Diabetes: a 21st century challenge. Lancet Diabetes Endocrinol 2: 56-64. [Crossref]

10. Fuchs S, Henschke C, Blumel M, Busse R (2014) Disease management programs for type 2 diabetes in Germany; a systematic literature review evaluating effectiveness. Dtsch Arztebl Int 111: 453-463. [Crossref]

11. Aggarwei R, Jain SK (2017) Obesity and metabolic phenotypes. EC Diabetes \& Metabolic Res 1: 11-12.

12. Singh A, Srivastav R, Randey AK (2017) Protective role of Terminalia Chebula in streptozotocin-induced diabetic mice for wound healing activity. $\mathrm{Br} J \mathrm{Med}$ Med Res 22: $1-8$.

13. Lu DY, Che JY, Wu HY, Lu TR (2014) The pathogenesis and treatments of diabetes, questions and answers. Cell Dev Biol 3: e126.

14. Lu DY, Che JY, Wu HY, Lu TR (2014) The pathogenesis and treatments of diabetes, a new insight. Advanced Techniques in Biology \& Medicine 2: e102.

15. Asche C, Lafleur J, Conner C (2011) A review of diabetes treatment adherence and the association with clinical and economic outcomes. Clin Ther 33: 74-109. [Crossref]

16. Closa DKJ. Masbang A, Cabrera DS, Dampil A, Mirasol R (2017) Effects of bariatric surgery on glucose control, weight reduction and disease remission among patients with type 2 diabetes mellitus; A systematic review and meta-analysis. EC Diabetes \& Metabolic Res 1: 29-48.

17. Correa-Giannella ML, Machado UF (2013) SLC2A4 gene: a promising target for pharmacogenomics of insulin resistance. Pharmacogenomics 14: 847-850.

18. Lander ES (2011) Initial impact of the sequencing of the human genome. Nature 470: 187-197. [Crossref]

19. Rahimzadeh V, Bartlett G (2017) Policies and practices of data-intensive primary care in the precision-medicine era. Internal Medicine Rev 3: 1-14.

20. Lu DY, Che JY (2014) Rethink of diabetes treatment and drug development. Cell Dev Biol 3: e125.

21. Lu DY, Wu HY, Yarla NS, Xu B, Ding J, et al. (2018) HAART in HIV/AIDS Treatments Future Trends. Infect Disord Drug Targets 18: 15-22. [Crossref]

22. Lu DY, Lu TR, Cao S (2013) Drug combinations in cancer treatment. Clin Exp Pharmacol 3: 134

23. Lu DY, Chen EH, Wu HY, Lu TR, Xu B, et al. (2017) Anticancer Drug Combinations, How Far We can Go Through? Anticancer Agents Med Chem 17: 21-28. [Crossref]

24. Lu DY, Lu TR, Yarla NS, Wu HY, Xu B, et al. (2017) Drug combination in clinical cancer treatment. Reviews on Recent Clinical Trials 12: 202-211

25. Lu DY, Lu TR, Lu Y, Sastry N, Wu HY (2016) Discover natural chemical drugs in modern medicines. Metabolomics 6: 181.

26. Putta S, Yarla NS, Peluso I, Tiwari DK, Reddy GV, et al. (2017) Anthocyanins: Possible role as multitarget therapeutic agents for prevention and therapy of chronic diseases. Current Pharmaceutical Design 23: 6321-6346.

27. Alam F, Islam MA, Kamal MA, Gam SH (2016) Updates on managing type 2 diabetes mellitus with natural products. Towards antidiabetic drug developments. Current Medicinal Chemistry 23: 1-37.

Copyright: (C2018 Lu D. This is an open-access article distributed under the terms of the Creative Commons Attribution License, which permits unrestricted use, distribution, and reproduction in any medium, provided the original author and source are credited. 